\title{
The First Record of Late Miocene Bat from European Russia
}

\author{
Valentina V. RossinA, Sergey V. KrusKop, Aleksey S. TESAKOV and Vadim V. TITOV
}

Received: 27 Dec., 2005

Accepted: 23 March, 2006

V. Rossina V. V., Kruskop S. V., Tesakov A. S., Titov V. V. 2006. The First Record of Late Miocene Bat from European Russia. Acta zoologica cracoviensia, 49A(1-2): 125-133.

Abstract. A single bone fragment of a Vespertilionine bat was discovered in the rich Late Turolian (MN12-13) vertebrate fauna of Morskaya 2 site near Taganrog (Sea of Azov region). This is the first record of bat remains from Late Miocene deposits of the European Russia. The morphology of the discovered fossil, represented by mandibular fragment with two molars, resembles the recent genera Vespertilio and Eptesicus. Comparative analysis with recent and fossil species of these two taxa allows us to assign this fossil to Vespertilio cf. villanyiensis.

Key words: Vespertilionini, Late Miocene, Sea of Azov region, Russia.

Valentina V. RossinA, Paleontological Institute RAS, Profsoyuznaya str., 123, 117997 Moscow, Russia.

E-mail: ros@paleo.ru

Sergey V. KRUSKOP, Zoological Museum of Moscow State University, Bolshaya Nikitskaya str., 6, 103009 Moscow, Russia.

E-mail: kruskop@zmmu.msu.ru; selysius@mail.ru

Aleksey S. TESAKOv, Geological Institute RAS, Pyzhevsky str., 7, 119017, Moscow, Russia, E-mail: tesak@ginras.ru

Vadim V. TITOV, South Scientific Center RAS, Chekhov str., 41, 344006, Rostov-on-Don, Russia.

E-mail: vvtitov@yandex.ru

\section{INTRODUCTION}

Fossil records of Vespertilionidae in European assemblages are very rare until the beginning of the middle Miocene when compared to the common and numerous records of Rhinolophids, Hipposiderids and Megadermatids. There are only few early Miocene deposits in Europe where Vespertilionids predominate: Schaffhausen 1 (Germany, MN1), Sansan (France, MN6) (BAUDELOT 1970, 1972) and a number of sites in the NW Bohemian brown coal basins (MN3-5, Czechia) (HORÁČEK 2001).

The Miocene is a key period in the evolution of the Vespertilionidae. At this time a significant species radiation of this family took place (SIGE \& LEGENDRE 1983). Climatic deterioration and pronounced seasonality occured during the late Neogene and disadvantaged most specialized representatives of the Emballonurids and the Mollosids. In contrast, the Vespertilionids apparently profited from the disappearance of these bats by taking a wider range of habitats (HORÁČEK 2001). 
The overwhelming majority of Neogene and Quaternary bat records comes from karstic deposits. A rich bat fauna is known from the cave deposits of Podlesice (Kraków-Częstochowa Upland, Poland). This fauna, whose age is Lower Pliocene (early Ruscinian), contains remarkable fossil bat remains representing the family Vespertilionidae (KOWALSKI 1974; WOŁOSZYN 1987).

Bat remains from alluvial deposits are badly documented. Most Quaternary orictocenoses also have karstic origins. The only assemblages of bats from alluvial deposits are known from Pleistocene of Hungary (KRETZOI 1956; TOPAL 1981) and Austria (RABEDER 1973).

Records of bat remains older than Middle Pleistocene were unknown from European Russia until now. Therefore, the discovery of Chiropteran fossil in a fluvial deposit at Morskaya 2 near Taganrog (Sea of Azov region, $47^{\circ} 17.5^{\prime} \mathrm{N} 39^{\circ} 06.0^{\prime} \mathrm{E}$ ) is very important.

The varied and rich vertebrate fauna from the Late Miocene site at Morskaya 2 was recently reported by TESAKOV \& TITOV (2003) after extensive excavations and screen washing operations. The mammalian fauna currently includes more than twenty forms, with the rabbit Hypolagus igromovi GUREEV 1964 and mice of the genera Apodemus and Occitanomys dominating. The locality, initially described by V. V. BoGATCHEV (1918), was originally dated to the Late Pliocene (e.g. POPOV 1948; VASILIEV 1969). At present, the faunal composition gives a date of Late Miocene, Turolian, zones MN12-13. This corresponds to the Maeotian-Early Pontian of the Black Sea marine stages.

A c k n o w 1 e d g e m e $n$ t s. The authors are grateful to Prof. Dr. A. K. AgAdjanian (Paleontological Institute, Russian Academy of Sciences) for valuable discussions. We would like to thank Prof. Dr. A. NADAChowski, Prof. Dr. K. Kowalski and Prof. Dr. B. W. Woloszyn (Institute of Systematics and Evolution of Animals, Polish Academy of Sciences) who made their collection and reprints available. Thanks are also due to Dr. T. POSTAWA and K. OCHMAN, M.Sc. for the assistance. This study was supported by the Russian Foundation for Basic Research (projects nos. 04-05-64805, 05-04-48493), the Board of the President of the Russian Federation (project no. NSh-1840.2003.4), the Complex Program for Basic Research of the Presidium of the Russian Academy of Sciences (no. 25 "Biosphere Origin and Evolution"), and the Program of the Presidium of the Russian Academy of Sciences "Historical Dynamics of Bioresources As a Prerequisite for Their Conservation and Harmonious Exploitation."

\section{MATERIAL AND METHODS}

The investigated specimen was measured by binocular microscope with ocular micrometer. The 11 measurements were taken to the nearest $0.01 \mathrm{~mm}$. The dimensions of lengths for individual teeth and tooth row: from mesial to distal margins of crowns respectively. The dimensions of tooth width: overall distance from lingual to buccal margins of crowns. During measuring the tooth was oriented with the conids vertical in occlusal view. The abbreviations are $\mathrm{M}_{1-3}=$ length of $\mathrm{M}_{1-3} ; \mathrm{M}_{1-2}=$ length of $\mathrm{M}_{1-2} ; \mathrm{M}_{1}=$ length of $\mathrm{M}_{1} ; \mathrm{M}_{2}=$ length of $\mathrm{M}_{2} ; \mathrm{CM}_{1}=$ length of $\mathrm{CM}_{1} ; \mathrm{CM}_{3}=$ length of $\mathrm{CM}_{3} ; \mathrm{Hmd}=$ height of corpus mandibulae measured on the lingual side below $\mathrm{M}_{1} ; \operatorname{tr} \mathrm{M}_{1}=$ width of $\mathrm{M}_{1}$ trigonid; $\operatorname{tr} \mathrm{M}_{2}=$ width of $\mathrm{M}_{2}$ trigonid; $\mathrm{tlM}_{1}=$ width of $\mathrm{M}_{1}$ talonid; $\mathrm{tlM}_{2}=$ width of $\mathrm{M}_{2}$ talonid.

Reference material, deposited at the Zoological Museum of Moscow University was used for the comparison of the investigated specimen. We used 11 specimens of Vespertilio murinus LiNNAEUS, 1758 non SCHREBER, 1775, 11 of Eptesicus (Amblyotus) nilssonii (KEYSERLING \& BLASIUS, 1839), 5 of Eptesicus (?Amblyotus) gobiensis BoBRINSKOY, 1926, a single Eptesicus (?Amblyotus) bobrinskoi KUZYAKIN, 1935 and two of Eptesicus (Eptesicus) bottae (PETERS, 1869). The similarly constructed Hypsugo savii (BONAPARTE, 1837) was rejected in this analysis because of its distinctly smaller size. Right mandibular branches of fully-grown specimens were used, from which a set of twenty measurements were taken.

Data was processed by the Statistica for Windows 5.1 software package. Numerical data were standardized with respect to dispersion to minimize size influence and then analyzed with Discriminant Function and Principal Component Analysis. In DF the analysed fossil specimen was included as undetermined. 


\section{SYSTEMATIC PALEONTOLOGY}

\section{Order Chiroptera BlumenBACH, 1779}

Suborder Microchiroptera DOBSON, 1875

Family Vespertilionidae GRAY, 1821

Tribe Vespertilionini s. str.

Vespertilio cf. villanyiensis HORÁČEK 1997

$\mathrm{D}$ e s c r i p t i o n. The specimen (coll. of Taganrog Pedagogical Institute, TGPI, No M-2/66) is represented by a right lower jaw with damaged ends: the posterior part is broken at the retromolar zone and the anterior part at the level of canine alveolus. The $M_{1}$ and $M_{2}$ have damaged hypoconide areas (see Fig. 1). Only the roots of the $\mathrm{M}_{3}$ are present in its alveoli. At the anterior end two $\mathrm{P}_{4}$ alveoli and one for the $\mathrm{P}_{2}$ are present. The number of alveoli suggests the whole dental formula of lower jaw is: $\mathrm{I}_{\overline{2}} \mathrm{C}_{\overline{1}} \mathrm{P}_{\overline{2}} \mathrm{M}_{\overline{3}}$.

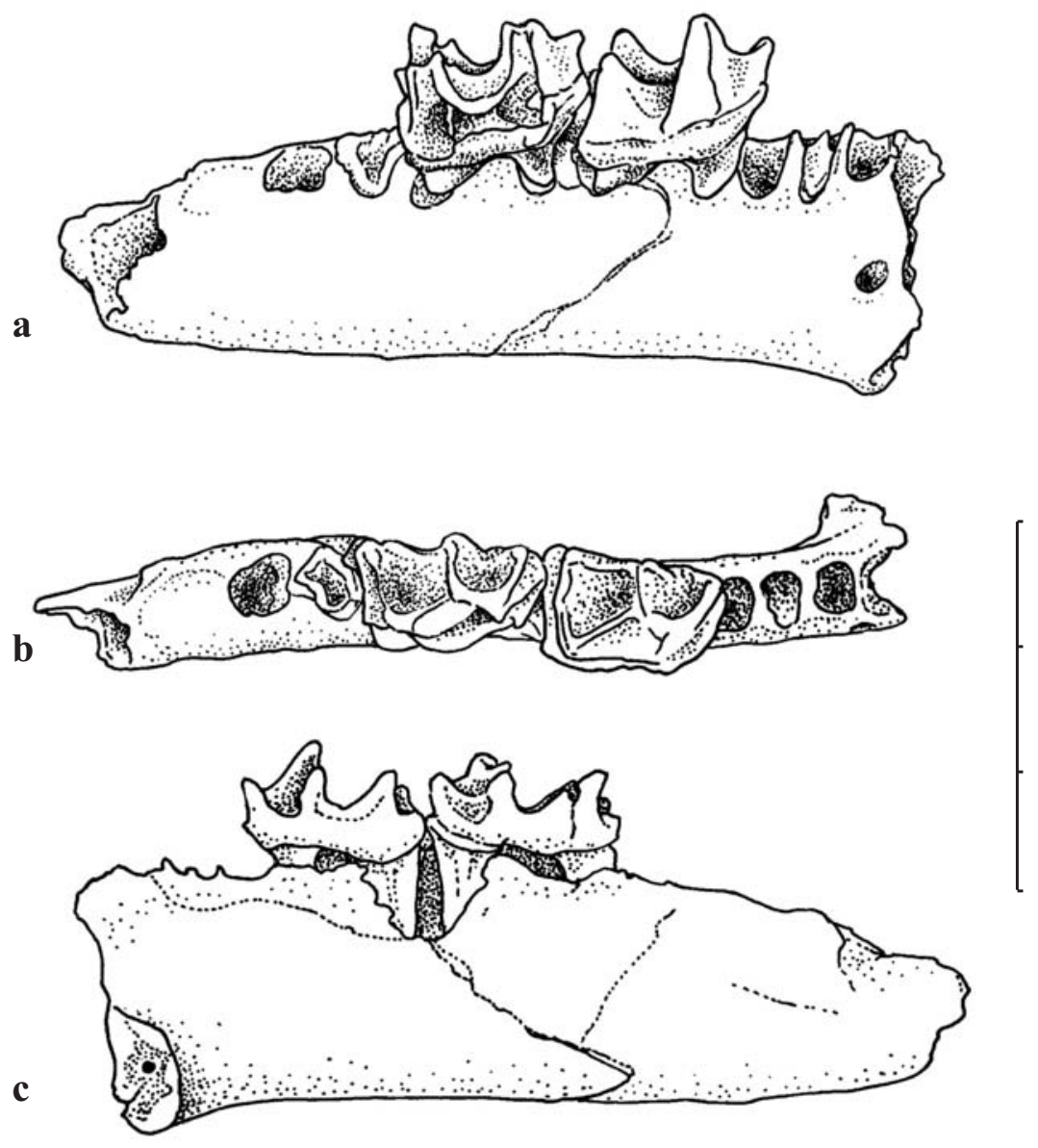

Fig. 1. Lower jaw of Vespertilio cf. villanyiensis: a - buccal view; $\mathrm{b}-$ view from above; $\mathrm{c}-$ lingual view. Scale $=3 \mathrm{~mm}$. 
$\mathrm{P}_{2}$ : single-rooted apparently conical tooth, probably slightly compressed in antero-posterior direction because of its oval alveolus.

$\mathrm{P}_{4}$ : the alveoli shape suggests that it is a two-rooted tooth with more reduced first root than the second, as in recent Eptesicus or Vespertilio.

$\mathrm{M}_{1}$ : two-rooted tooth; the second root larger than the first. The trigonid is higher than the talonid but more narrow in occlusal view. The highest cusp in the trigonid area is the protoconid and in the talonid area, the hypoconid. The paralophid is slightly convex in the anterior direction. The hypoconulid looks like a small cingular appendage. The crown is of the obvious myotodont type with a well-developed distinct cingulum. Like in many other representatives of the tribe Vespertilionini s. str., our specimen possesses an $\mathrm{M}_{2}$ that is almost identical to its $\mathrm{M}_{1}$ with some minor differences. The length of the $M_{1}$ slightly exceeds that of the $M_{2}$. The trigonid of the $M_{2}$ is more elongated in a bucco-lingual direction, thus in occlusal view it looks shorter but wider than that of the $\mathrm{M}_{1}$.

The shape of the alveoli of the $\mathrm{M}_{3}$ suggests that the degree of reduction of this tooth is similar to that of the recent Eptesicus (Amblyotus) or Vespertilio. In the described sample a part of a mandible symphysis is also included, which begins at the middle point of the $\mathrm{P}_{2}$. The mental foramen is positioned at the $\mathrm{P}_{2}$ level, almost at the mid-line of the lower jaw (see Fig. 1a).

$\mathrm{C}$ o $\mathrm{m} \mathrm{p}$ a $\mathrm{r}$ i s o $\mathrm{n}$. The following Neogene and early Anthropogene bat species, similar to the recent genera Vespertilio and Eptesicus, were described from Europe up to the present time: $\mathrm{Pa}$ leptesicus priscus ZAPFE 1950, Eptesicus campanensis BAUDELOT 1970, E. aurelianensis ZIEGLER 1993, E. noctuloides LARTET 1851, E. praeglacialis KORMOS 1930, E. kowalskii WoŁOSZYN 1987, E. mossoczyi WolosZYN 1987, Samonycteris majori REVILlod 1922, Vespertilio villanyiensis HORÁČEK 1997 (nomen nov. pro V. majori KORMOS 1934 non NINNI 1878), Hanakia fejfari HORÁČEK 2001, Miostrellus riesgoviensis RACHL 1983, and M. egeriensis HORÁČEK 2001. The systematic positions and possible relationships of the majority of these species are not clear and need additional fossil evidence. Unfortunately, the morphological comparison of our specimen with some of the named fossil species is impossible. The lower jaw and teeth of the Paleptesicus priscus are unknown (ZAPFE 1950, 1970; HORÁČEK 2001). The last author noted the considerable morphological specificity of $P$. priscus and its possible relations with the recent South Asian genus Eudiscopus, which seems to be very distant taxonomically from Eptesicoids (KRUSKOP et al. 2003). Miostrellus egeriensis is known from a calvarium, impressed into a clay stone, and a latex cast of the left maxillary row (HORÁČEK 2001). Therefore, comparison of our specimen with this species is also impossible.

Attribution of our specimen to the monotypic genus Samonycteris, described from Middle Miocene of Samos Island (Greece) (REVILLOD 1922; ZIEGLER 2002), seems to be very doubtful. The S. majori stands out from other European fossil Vespertilionids by lacking an I ${ }^{2}$ (MENU 1987) and thus looks similar to recent genera Scotophylus and Nycticeinops.

The Early Miocene Myotis-like species Hanakia fejfari, included by HORÁČEK (2001) into the Eptesicini tribe, has three lower premolars, as in Myotis and Plecotus, and a strongly reduced $\mathrm{M}_{3}$, like in recent Eptesicus s. str. and specially in Eptesicus serotinus.

E. campanensis, known from the Middle Miocene of France and Portugal (BAUDELOT 1972; ANTUNES \& MEIN 1977), is notably bigger than the specimen from the Sea of Azov region (see Table I). It has robust teeth and a considerably reduced $\mathrm{M}_{3}$, like in recent E. serotinus (HORÁČEK 2001), while the alveoli shape of our specimen suggests the moderate degree of $\mathrm{M}_{3}$ talonid reduction. E. kowalskii, described from Podlesice (central part of Kraków-Częstochowa Upland, Poland), is close in size to the recent E. serotinus and E. campanensis (WoŁOSZYN 1987).

The Early Pleistocene species E. praeglacialis is morphologically similar to the recent $E$. serotinus but somewhat larger. All these forms, and also E. aurelianensis from the Lower Miocene of Bavaria (ZEIGLER 1993; HORÁČEK 2001), exceed the Azov specimen in size (see Table I). In contrast, Amblyotus-like E. noctuloides from the Miocene of France (BAUDELOT 1972) is smaller than our specimen (see Table I). 
Late Miocene Bat from European Russia

告

\begin{tabular}{|c|c|c|c|c|c|c|c|c|c|c|c|c|}
\hline 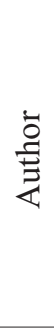 & 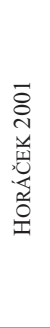 & 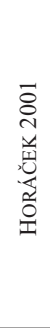 & 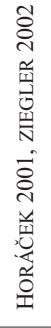 & 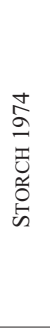 & 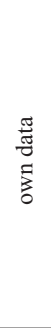 & 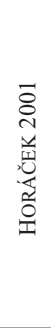 & $\begin{array}{l}\text { 㺃 } \\
\text { 苛 }\end{array}$ & 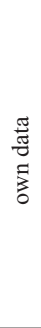 & 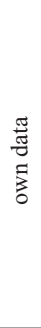 & 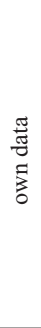 & 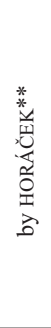 & $\begin{array}{l}\text { 节 } \\
\text { है } \\
\text { है }\end{array}$ \\
\hline$\sum^{N}$ & $\stackrel{\infty}{\infty}$ & & $\vec{n}$ & & $\overrightarrow{\stackrel{I}{\longrightarrow}}$ & & $\begin{array}{l}0 \\
\infty \\
0 \\
\grave{d} \\
\infty \\
0\end{array}$ & $\begin{array}{l}\text { ñ } \\
\hat{1} \\
1 \\
0 \\
0 \\
0\end{array}$ & 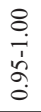 & $\begin{array}{l}\stackrel{8}{0} \\
\frac{1}{\circ} \\
\stackrel{5}{\circ}\end{array}$ & $\underset{\sim}{\stackrel{t}{*}}$ & \\
\hline$\sum_{\Xi}^{N}$ & 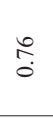 & & $\stackrel{⿱ 艹 冖}{\longrightarrow}$ & & $\stackrel{ \pm}{\rightleftarrows}$ & & $\begin{array}{l}0 \\
0 \\
0 \\
10 \\
\infty \\
0 \\
0\end{array}$ & $\begin{array}{l}n \\
0 \\
0 \\
\vdots \\
\\
0 \\
0\end{array}$ & $\begin{array}{l}8 \\
\circ \\
0 \\
0 \\
\infty \\
0\end{array}$ & $\begin{array}{l}8 \\
0 \\
0 \\
1 \\
\infty \\
0 \\
0\end{array}$ & $\stackrel{8}{8}$ & \\
\hline$\Sigma^{N}$ & $\stackrel{\check{c}}{\leftrightarrows}$ & & $\stackrel{\vec{i}}{\vec{i}}$ & & $\stackrel{\infty}{\rightarrow}$ & & $\begin{array}{l}\hat{n} \\
\stackrel{n}{b} \\
\stackrel{n}{-}\end{array}$ & 究 & 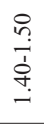 & 桨 & $\stackrel{?}{\stackrel{f}{-}}$ & 䓵 \\
\hline$\sum$ & $\begin{array}{l}\infty \\
\infty \\
0\end{array}$ & & $\stackrel{\infty}{\stackrel{\infty}{\rightarrow}}$ & & 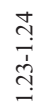 & & & $\begin{array}{l}\text { مू } \\
\hat{o} \\
\dot{1} \\
0 \\
0\end{array}$ & $\begin{array}{l}8 \\
\frac{1}{1} \\
\stackrel{\alpha}{0}\end{array}$ & 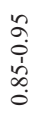 & $\stackrel{+}{\stackrel{t}{-}}$ & \& \\
\hline$\sum_{\Xi}^{\bar{E}}$ & $\stackrel{n}{\stackrel{n}{0}}$ & & $\stackrel{\overbrace{}}{\stackrel{\overbrace{}}{9}}$ & & $\begin{array}{l}\stackrel{8}{\overrightarrow{+}} \\
\text { 它 } \\
\text {. }\end{array}$ & & & $\begin{array}{l}\infty \\
0 \\
0 \\
0 \\
0 \\
0 \\
0\end{array}$ & $\begin{array}{l}n \\
\infty \\
0 \\
\hat{1} \\
\hat{0} \\
0\end{array}$ & $\begin{array}{l}\stackrel{8}{0} \\
0 \\
0 \\
0 \\
0 \\
0\end{array}$ & $\stackrel{8}{\circ}$ & $\begin{array}{l}\infty \\
0 \\
0\end{array}$ \\
\hline $\bar{\Sigma}$ & $\stackrel{?}{?}$ & & $\stackrel{m}{i}$ & & 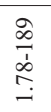 & & & $\begin{array}{l}n \\
\text { in } \\
\text { d } \\
\text { n. }\end{array}$ & 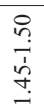 & 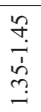 & 嵒 & $\stackrel{8}{:}$ \\
\hline$\sum_{U^{\prime}}^{\infty}$ & & & $\begin{array}{l}0 \\
\infty\end{array}$ & $\begin{array}{l}\infty \\
\infty \\
\infty \\
0 \\
\infty\end{array}$ & $\frac{\tilde{n}}{i}$ & $\begin{array}{l}\tilde{o} \\
\dot{+} \\
\tilde{r} \\
\dot{y}\end{array}$ & $\begin{array}{l}3 \\
\text { id } \\
\text { in }\end{array}$ & $\begin{array}{l}0 \\
0 \\
1 \\
\dot{j} \\
\dot{b} \\
\dot{n}\end{array}$ & 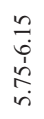 & $\begin{array}{l}n \\
6 \\
n \\
n \\
n \\
n\end{array}$ & तु & $\begin{array}{l}\text { * } \\
\text { 它 } \\
\text { in } \\
?\end{array}$ \\
\hline$\sum_{U^{\prime}}^{\bar{S}}$ & & $\frac{6}{6}$ & & & 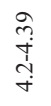 & & $\begin{array}{l}\stackrel{0}{\infty} \\
\text { i }\end{array}$ & $\begin{array}{l}m \\
\stackrel{m}{n} \\
\stackrel{n}{m}\end{array}$ & $\begin{array}{l}\stackrel{r}{r} \\
\stackrel{\dot{u}}{\sim} \\
\dot{m}\end{array}$ & $\begin{array}{l}\stackrel{n}{a} \\
\stackrel{i}{i} \\
i\end{array}$ & $\stackrel{m}{m}$ & $\begin{array}{l}* \\
\text { * } \\
0 \\
ن\end{array}$ \\
\hline$\vec{\Xi}$ & & & $\stackrel{\mathfrak{n}}{i}$ & & 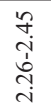 & & $\begin{array}{l}\hat{\sigma} \\
\stackrel{+}{+} \\
\stackrel{0}{+} \\
\stackrel{+}{+}\end{array}$ & $\begin{array}{l}n \\
n \\
n \\
n\end{array}$ & 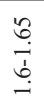 & $\underbrace{\infty}_{\substack{b\\
}}$ & & $\stackrel{\infty}{\infty}$ \\
\hline$\stackrel{\Gamma}{\Sigma}$ & 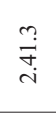 & & & & $\begin{array}{l}\hat{R} \\
i \\
\dot{m}\end{array}$ & & $\stackrel{n}{i}$ & $\begin{array}{l}\infty \\
\text { îj } \\
\text { S. }\end{array}$ & $\begin{array}{l}n \\
n \\
r \\
b \\
b \\
i\end{array}$ & 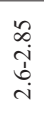 & त्रे & $\stackrel{*}{\stackrel{*}{m}}$ \\
\hline$\sum_{\Sigma}^{M}$ & $\stackrel{n}{m}$ & & in & $\begin{array}{l}\hat{n} \\
\hat{b} \\
\infty \\
i \\
i\end{array}$ & $\begin{array}{l}\stackrel{9}{i} \\
i \\
i\end{array}$ & $\begin{array}{l}n \\
n \\
m \\
b \\
b \\
\dot{m}\end{array}$ & $\stackrel{\infty}{i}$ & 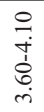 & 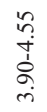 & $\begin{array}{l}n \\
n \\
+ \\
0 \\
\infty \\
n \\
n\end{array}$ & 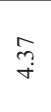 & 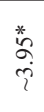 \\
\hline Z & & & & & & & $N$ & $=$ & 6 & $=$ & - & - \\
\hline $\begin{array}{l}\frac{\tilde{u}}{\tilde{J}} \\
\text { की } \\
\text { की }\end{array}$ & 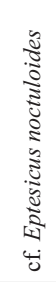 & 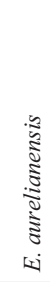 & 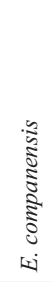 & 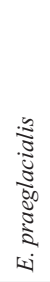 & 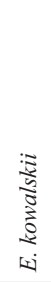 & 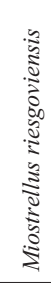 & 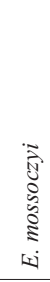 & 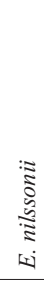 & 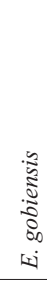 & 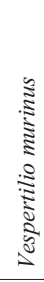 & 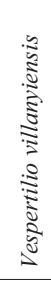 & 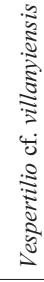 \\
\hline
\end{tabular}


E. mossoczyi, the second Eptesicus species described from Podlesice, was a smaller form, similar in size to recent $E$. nilssonii (see Table I). However, this fossil species has a number of features which can be interpreted as progressive. As it was supposed by WOŁOSZYN (1987), it is more likely that E. mossoczyi represents a separate terminal stage of an extinct phyletic line of Eptesicus.

Apparently the lower jaw from the Sea of Azov region looks most similar to the Early Pleistocene species Vespertilio villanyiensis from the Hungarian site Villány-Kalkberg (Villány 3 sensu KRETZOI 1956), which is most likely a synonym of Vespertilio murinus LINNAEUS 1758 (HORÁČEK 1997). However, the foramen mentale of our specimen and Vespertilio villanyiensis (see Fig. 1a) is situated at the mid-line of the jaw branch, in contrast to the recent Vespertilio murinus, in which it is usually displaced downward (see Fig. 2). The fossil record of the genus Vespertilio is sparse. The only known fossil species differs from the recent Vespertilio mainly in the less compressed unicuspid teeth in which it is somewhat similar to Amblyotis (HORÁČEK 2001). The latter feature can be seen in our specimen also. The affiliation of the jaw fragment from the Sea of Azov Region to the genus Vespertilio is also supported by the results of its comparison with recent Palaearctic representatives of the genera Vespertilio and Eptesicus.

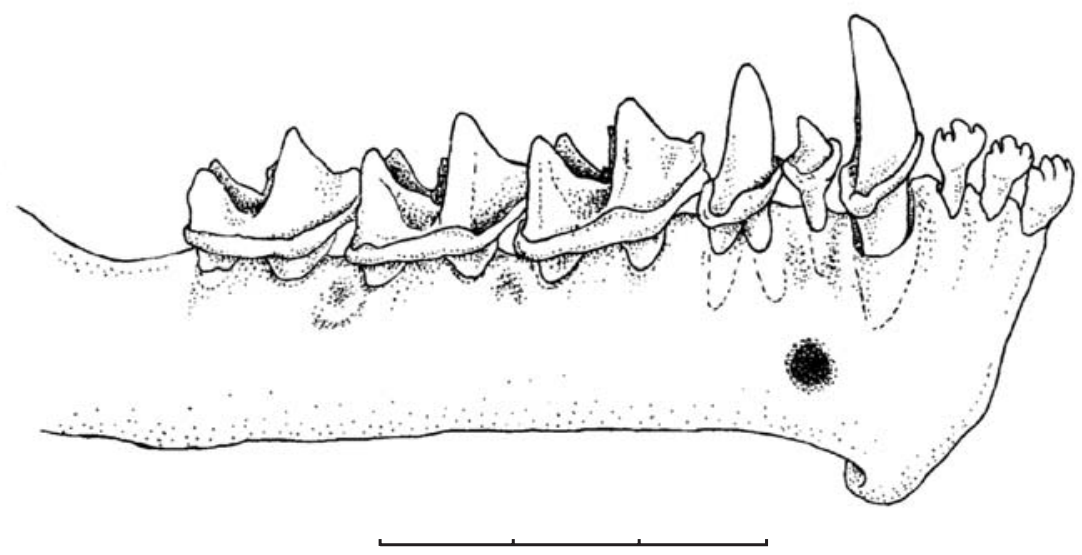

Fig. 2. Position of foramen mentale of Vespertilio murinus: buccal view. Scale $=3 \mathrm{~mm}$.

In the scatterplots in Figs. 3-4 the two first Principal Components, and Discriminant Functions of the four recent species V. murinus, E. nilssonii, E. gobiensis, and E. bobrinskoi are shown together with our specimen (marked as $V$. cf. villanyiensis). Unfortunately, no fossil specimens (including the type of $V$. villanyiensis) could be used in the same analysis, since some of the measurements upon them were missing.

In both cases (see Fig. 4) we have two major, well-segregated clusters, formed by the Vespertilio and Amblyotus specimens, respectively. In the case of the DF analysis (see Fig. 3) specimens of Eptesicus bottae are situated outside and at a distance from both of these clusters, however the PCA (see Fig. 4) combined them with Vespertilio. In both cases the investigated fossil specimen demonstrates distinctly higher affiliation with Vespertilio than with Eptesicus. Nevertheless, the Squared Mahalanobis distance of this specimen from recent $V$. murinus (251.75) exceeds that between species of Eptesicus (Amblyotus) (74.84) and even between E. nilssonii and V. murinus (188.11), demonstrating a high level of specific distinctiveness.

Based on the morphological data, we suggest that the Late Miocene specimen from the Sea of Azov Region of European Russia most likely belongs to the genus Vespertilio. 


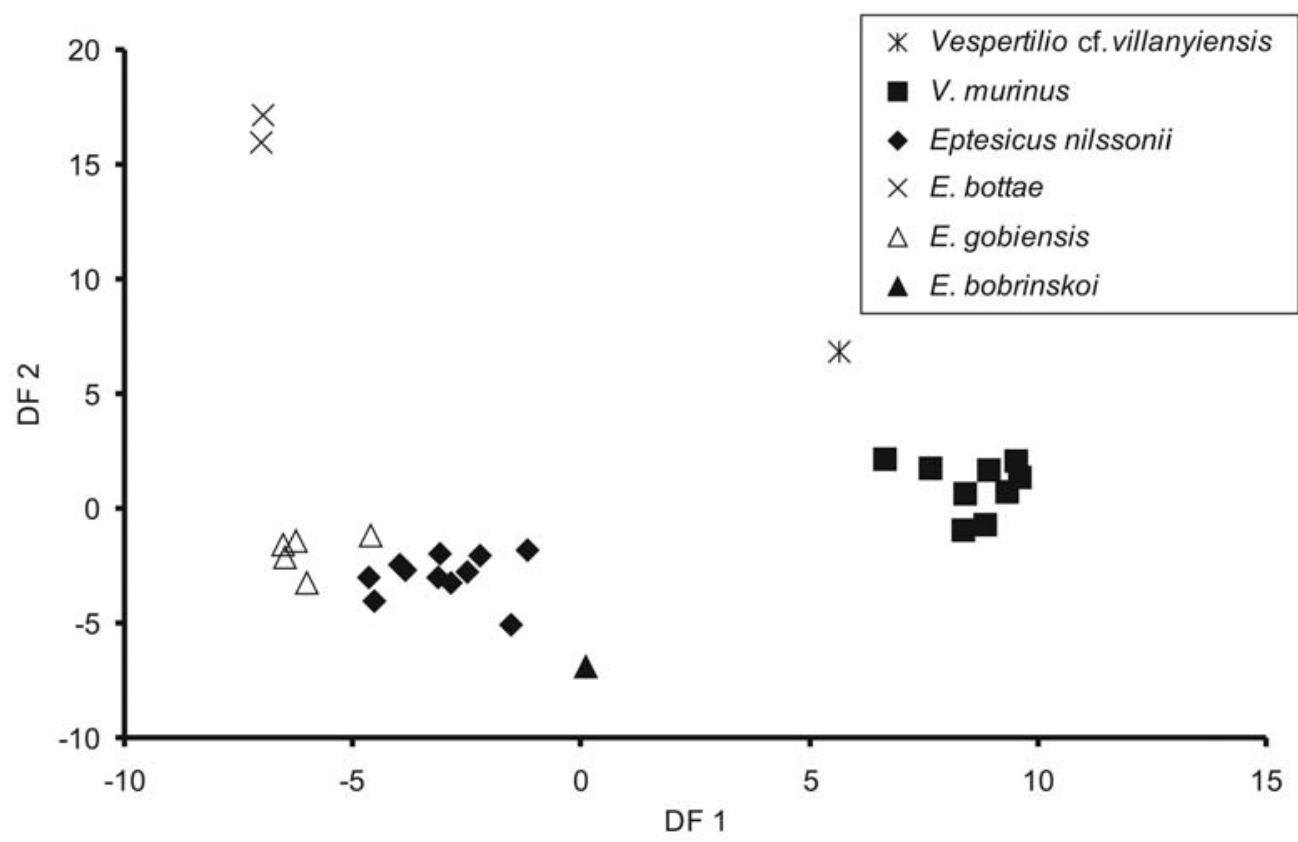

Fig. 3. Scatterplot of the first two discriminant functions for Eptesicus species, Vespertilio cf. villanyiensis and V. murinus.

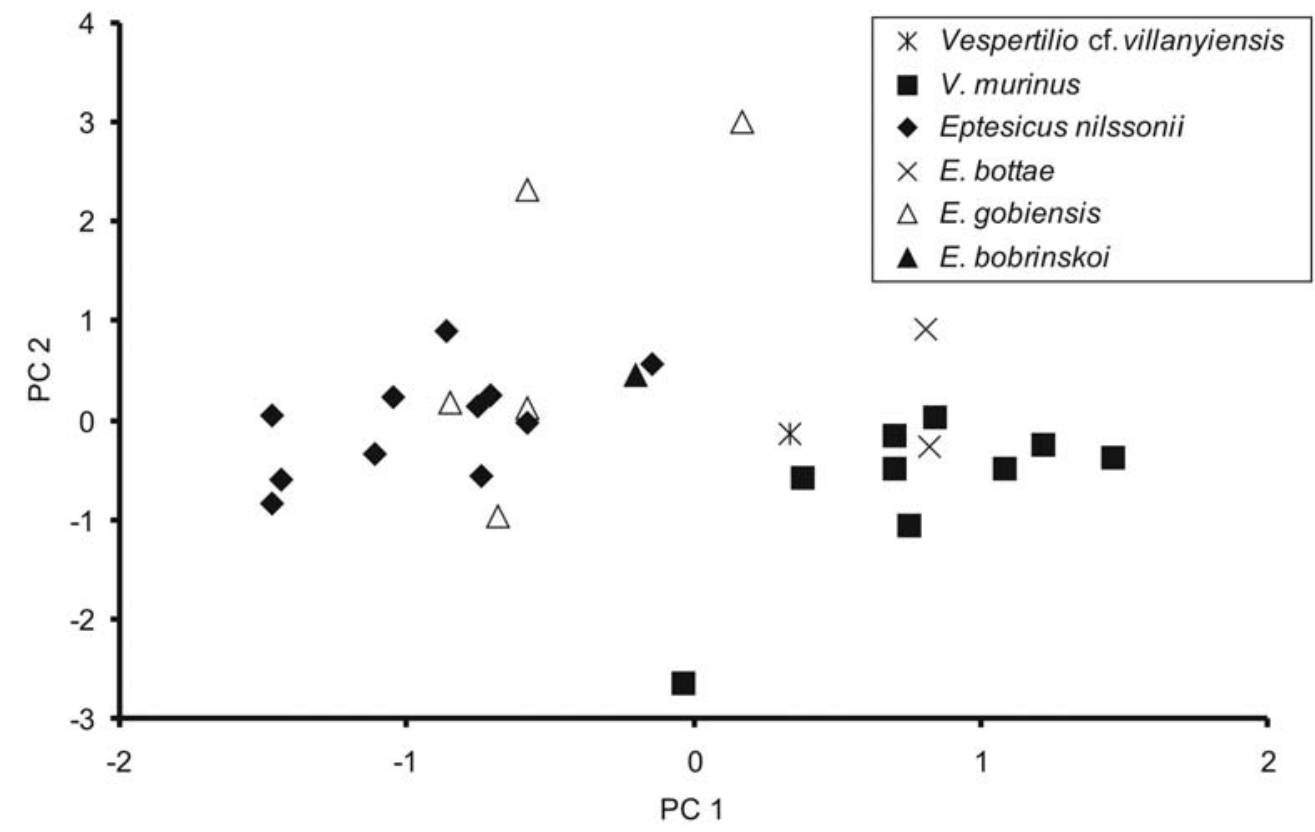

Fig. 4. Scatterplot of the first two principal components for Eptesicus species, Vespertilio cf. villanyiensis and V. Murinus. 
The Azov specimen $V$. cf. villanyiensis looks morphologically similar to $V$. villanyiensis, however, it differs somewhat in certain measurements from the type specimen as described by HORÁČEK (1997). Thus, the length dimensions for the $\mathrm{M}_{2}$ and the length of $\mathrm{M}_{1-2}$ (see Table I) are larger in $V$. cf. villanyiensis. But these differences may appear as the result of damage to the Azov jaw between the $\mathrm{M}_{1}$ and the $\mathrm{M}_{2}$ (see Fig. 1), which was further reconstructed. Unfortunately, the crown of the $\mathrm{M}_{2}$ is also defective (see above).

The length of the $\mathrm{M}_{1}$ of $V$. cf. villanyiensis somewhat exceeds that of $V$. villanyiensis (see Table I). We suppose this difference may be the result of intraspecific size variability of individual teeth in the Vespertilio murinus group. Unfortunately, more detailed size comparison of $V$. villanyiensis and $V$. cf. villanyiensis is impossible because the Azov fossil specimen is quite fragmentary.

Taking into account all that mentioned above, we are unable to ascertain the exact specific affiliation of the Azov specimen, because of insufficient comparative material, thus we are obliged to use an open nomenclature and designate this specimen as $V$. cf. villanyiensis.

\section{REFERENCES}

ANTUNeS M. T., MeIN P. 1977. Contribution á la paléontologie du Miocéne moyen continental du bassin du Tage. III. Mammifères - Povoa de Santarem, Pero Filho et Choes (Secario). Conclusions générales. Ciencas da Terra (U.N.L.), 3: 143-165.

BAUDELOT S. 1970. Complméent á l'étude des Micromammifères de gisement miocnée de Sansan (GERS). Compte Rendu Sommaire des séances de la Société Géologique de France, 8: 303-304.

BAUDELOT S. 1972. Etude des chiroptères, insectivores et rongeurs du Miocène de Sansan. Thèse d'État, Universite Paul Sabatier, Toulouse, 364 pp.

BoGATCHEV V. V. 1918. Ocherki istorii i geographii Vsevelikogo voiska Donskogo. (Studies of the geography of the Don Cossacks region.) Rostov-Don. 520 pp. (In Russian).

HORÁČ́EK I. 1997. Comments on Vespertilio majori KORMOS, 1934. Vespertilio, 2: 131-133.

HORÁČEK I. 2001. On the early history of vespertilionid bats in Europe: the Lower Miocene record from the Bohemian Massif. Lynx (Praha), n. s., 32: 123-154.

KORMOS T. 1934. Neue Insktenfresser Fledermaüse und Nader aus dem Oberpliozän der Villányer Gegend. Földtani Közlöny, 64: 269-321.

KOWALSKI K. 1974. The vertebrate fauna of the Upper Pliocene and Villafranchian in Poland. Mémoire du Bureau de recherches géologiques et minières, 78: 197-202.

KRETZOI M. 1956. Die altpleistozänen Wirbeltierfaunen des Villányer Gebirges. Geologia Hungarica, Series Palaeontologica, 27: 1-264.

KRUSKOP S. V., TSYTSULINA E. A., MaSUdA P. 2003. Polozenie roda Eudiscopus (Mammalia, Chiroptera) v sisteme gladkonosikh rukokrilikh. (Position of genus Eudiscopus (Mammalia, Chiroptera) in system of Vespertilionidae). Teriofauna Rossii i sopredelnikh territorii. VII S'ezd Teriologicheskogo obshestva. Moskva. (Theriofauna of Russia and contiguous territories. VII Congress of All-Russian Theriological Society. Materials of international theriological conference, Moscow) pp. 183-184. (In Russian).

MENU H. 1987. Morphotypes dentaires actuels et fossiles des chiroptères vespertilionines. $2^{\mathrm{e}}$ partie: Implications systématiques et phylogéniques. Paléovertebrata, 17(3): 77-150.

POPOV G. I. 1948. Tanaiskie sloi drevnego Dona. (Tanais Beds of ancient Don). Bulleten' Komissii po izucheniyu chetvertichnogo perioda, 12: 55-68. (In Russian).

RABEDER G. 1973. Fossile Fladermausfaunen aus Österreich.Osterreich. Myotis, Mitteilungsblatt für fledermauskundler, 11: 3-14.

REVILLOD P. 1922. Contribution à l'étude des chiropteres des terrains tertiaires. 3 et fin. Mémoires de la Société paléontologique Suisse, 45: 133-195.

Sige B., LegendRE S. 1983. L'histoire des Peuplements de Chiroptères du bassin mediterraneen: l'apport comparé des remplissages karstiques et des dépôts fluvio-lacustres. Mémoires de Biospéologie, X: 209-225.

TESAKOV A. S., TITOV V. V. 2003. Novaya pozdnemiocenovaya teriofauna iz mestonakhozdenia Morskaya 2. (The new Late Miocene theriofauna from Morskaya 2 locality (the Sea of Azov Region, Russia)). Teriofauna Rossii i sopredelnikh territorii. VII S'ezd Teriologicheskogo obshestva. Moskva. (Theriofauna of Russia and contiguous territories. VII Congress of All-Russian Theriological Society. Materials of international theriological conference, Moscow), pp. 347-348. (In Russian).

TOPAL Gy. 1981. New fossil mouse-eared bat, Myotis kretzoii sp. n. from the Middle Pleistocene of Hungary (Mammalia: Chiroptera). Fragmenta Mineralogica et Paleontologica, 10: 59-64. 
VASILIEV Yu. M. 1969. Formirovanie antropogenovykh otlozhenii lednikovooi i vnelednikovoi zony (Formation of Anthropogene deposits of glacial and extraglacial zone). Nauka, Moscow. 182 pp. (In Russian).

Wotoszyn B. W. 1987. Pliocene and Pleistocene bats of Poland. Acta Palaeontologica Polonica, 32(3-4): 207-325.

ZAPFE H. 1950. Die fauna der mioznäen Spaltenflülung von Neudorf an der March (C.S.R.): Chiroptera. Sitzungsberichte / Akademie der Wissenschaften in Wien, Abt. 1, 159: 51-64.

ZAPFe H. 1970. Paleptesicus nom. nov. Fur. "Paraptesicus" (Chiroptera) aus der mioznäen Spaltenflülung von Neudorf an der March (CSSR). Sitzungsberichte der Mathematisch-Naturwissenschaftlichen Klasse, Österreichische Akademie der Wissenschaften, 6: 93-94.

ZIEGLER R. 1993. Die Chiroptera (Mammalia) aus dem Untermiozan von Wintershof-West bei Eichstatt (Bayern). Mitteilungen der Bayerische Staatssammlung für Palaontologie und Historische Geologie, 33: 119-154.

ZIEGLER R. 2002. Bats (Chiroptera, Mammalia) from Middle Miocene karstic fissure fillings of Petersbuch near Eichstätt, Southern Franconian Alb (Bavaria). - Geobios, 36: 447-490. 